Tersedia online di: http://ejournal-balitbang.kkp.go.id/index.php/jra

\title{
KETAHANAN IKAN TAMBAKAN (Helostoma temminkii) TERHADAP BEBERAPA PARAMETER KUALITAS AIR DALAM LINGKUNGAN BUDIDAYA
}

\author{
Otong Zenal Arifin\#, Vitas Atmadi Prakoso, dan Brata Pantjara \\ Balai Riset Perikanan Budidaya Air Tawar dan Penyuluhan Perikanan \\ (Naskah diterima: 17 Maret 2017; Revisi final: 5 Oktober 2017; Disetujui publikasi: 5 Oktober 2017)
}

\begin{abstract}
ABSTRAK
Ikan tambakan (Helostoma temminkii) adalah satu dari beberapa jenis spesies ikan air tawar yang ekonomis di Indonesia. Komoditas ini cukup digemari di beberapa wilayah Jawa, Sumatera, dan Kalimantan. Oleh karena itu, prospek pengembangan budidaya ikan tambakan merupakan hal yang penting. Tulisan ini bertujuan untuk mengetahui respons ketahanan ikan tambakan terhadap paparan beberapa parameter kualitas air. Seluruh kegiatan pengujian dilakukan di Balai Riset Perikanan Budidaya Air Tawar dan Penyuluhan Perikanan, Bogor. Ikan yang digunakan pada percobaan ini adalah ikan tambakan generasi kedua hasil domestikasi (panjang standar: 7,5 $\pm 0,28 \mathrm{~cm}$; bobot: $15,2 \pm 2,11 \mathrm{~g}$ ). Uji toleransi yang dilakukan meliputi ketahanan terhadap salinitas, $\mathrm{pH}$, suhu, dan oksigen terlarut. Jumlah ikan yang diuji untuk masing-masing parameter kualitas air yaitu 30 ekor pada perlakuan salinitas, pH, dan suhu, serta 40 ekor untuk pengujian toleransi terhadap oksigen terlarut dengan tiga kali ulangan pada masing-masing perlakuan. Berdasarkan data penelitian, ikan tambakan dapat bertahan hidup dan beraktivitas secara normal pada kisaran salinitas $\leq 10 \mathrm{ppt}$, pH 5-9, suhu $20-35^{\circ} \mathrm{C}$, dan kandungan oksigen terlarut $>3 \mathrm{mg} / \mathrm{L}$. Kisaran nilai pada parameter kualitas air di luar batas toleransi dapat berpengaruh negatif pada pertumbuhan dan sintasan ikan tambakan.
\end{abstract}

\section{KATA KUNCl: Helostoma temminkii; toleransi; parameter kualitas air; tingkah laku; sintasan}

ABSTRACT : Resilience of kissing gouramy (Helostoma temminkii) on several water quality parameters in aquaculture environment, By: Otong Zenal Arifin, Vitas Atmadi Prakoso, and Brata Pantjara

Kissing gouramy (Helostoma temminkii) is one of valued freshwater fish in Indonesia. This species is quite popular in some areas of Java, Sumatra, and Kalimantan. Therefore, the development of aquaculture for this species is essential. This paper was intended to determinethe response of fish resistanceto the exposure of several water quality parameters. All of the experiments were carried out at the Institute for Freshwater Aquaculture Research and Fisheries Extension, Bogor. The experimental fish used in the experiment were domesticated kissing gouramy ( $2^{\text {nd }}$ generation) with standard length of $7.5 \pm 0.28 \mathrm{~cm}$ and total weight of $15.2 \pm 2.11 \mathrm{~g}$. The tests, on the resistance to salinity, $\mathrm{pH}$, temperature, and dissolved oxygen. For each treatment, 30 fish were challenged with salinity, $\mathrm{pH}$, and temperaturetreatments, and 40 fish for oxygen tolerance treatment. All treatments were conducted with three replications. Based on the results, kissing gouramy could survive and behave normally in the range of $\leq 10 \mathrm{ppt}$ salinity, $\mathrm{pH} 5-9$, temperature $20-35^{\circ} \mathrm{C}$, and dissolved oxygen content of more than $3 \mathrm{mg} / \mathrm{L}$. The range of values on water quality parameters which exceeded the tolerance limit could result in the negative effect on the growth and survival of kissing gouramy.

KEYWORDS: Helostoma temminkii; tolerance; water quality parameters; behavior; survival

\section{PENDAHULUAN}

Ikan tambakan (Helostoma temminkii) merupakan salah satu ikan air tawar ekonomis di Indonesia. Ikan ini cukup digemari masyarakat di beberapa wilayah Jawa, Sumatera, dan Kalimantan sebagai ikan konsumsi dalam bentuk kering (ikan asin) maupun dalam keadaan

\footnotetext{
\# Korespondensi: Balai Riset Perikanan Budidaya Air Tawar dan Penyuluhan Perikanan. Jl. Sempur No. 1, Bogor 16154, Indonesia. Tel. + 622518313200

E-mail: zenalarifin@gmail.com
}

segar. Oleh karena itu, prospek pengembangan budidaya ikan tambakan sebagai salah satu sumber protein merupakan hal yang penting. Ikan tambakan merupakan salah satu komoditas potensial untuk dibudidayakan karena toleransinya terhadap lingkungan dan fekunditasnya tinggi (Efriyeldi \& Pulungan, 1995).

Sampai saat ini, produksi ikan tambakan masih bergantung dari hasil tangkapan di alam. Pemeliharaan dalam wadah yang terkontrol juga belum banyak dilakukan oleh pembudidaya ikan (Yurisman, 2009). 
Pada saat pemeliharaan, kondisi fisik dan kimia lingkungan memiliki pengaruh yang besar terhadap fisiologi dari ikan. Faktor pembatas berupa parameter kualitas air dapat menyebabkan penyakit dan kematian. Paparan berulang yang melebihi batas toleransi akan berpengaruh negatif terhadap kesehatan dan sintasan ikan, sehingga ikan menjadi maladaptif (Selye, 1974; Barton \& Iwama, 1991).

Parameter kualitas air yang nilainya melebihi batas toleransi bagi ikan tertentu dapat menyebabkan stres yang memengaruhi kesehatan dan produksi budidaya. Beberapa penelitian telah dilakukan untuk mengetahui respons ikan terhadap paparan beberapa parameter lingkungan (Ayala et al., 2016; Lorenz et al., 2015; Bonis ${ }^{3}$ awska et al., 2014; Ath-thar \& Gustiano, 2010; Scott et al., 2005; Ito \& Yada, 1997). Dari beberapa penelitian tersebut, dapat disimpulkan bahwa beberapa parameter kualitas air yang umumnya berpengaruh terhadap sintasan ikan di lingkungan budidaya antara lain yaitu salinitas, suhu, pH, dan oksigen terlarut. Berdasarkan informasi tersebut, penelitian mengenai ketahanan ikan tambakan (Helostoma temminkii) terhadap keempat parameter kualitas air tersebut untuk keperluan budidaya masih belum banyak dipelajari. Tulisan ini bertujuan untuk mengetahui respons ketahanan ikan tambakan terhadap paparan beberapa tingkat salinitas, $\mathrm{pH}$, dan suhu, serta mengetahui kadar oksigen terlarut letalnya.

\section{BAHAN DAN METODE}

Seluruh kegiatan pengujian dilakukan di Balai Riset Perikanan Budidaya Air Tawar dan Penyuluhan Perikanan, Bogor. Ikan yang digunakan pada percobaan ini adalah ikan tambakan G2 hasil domestikasi dengan ukuran panjang standar 7,5 \pm $0,28 \mathrm{~cm}$ dan bobot $15,2 \pm 2,11 \mathrm{~g}$. Uji toleransi beberapa parameter kualitas air yang dilakukan meliputi ketahanan terhadap salinitas, pH, suhu, dan oksigen terlarut. Jumlah ikan yang diuji untuk masingmasing pengujian adalah 30 ekor pada perlakuan salinitas, pH, dan suhu, serta 40 ekor untuk pengujian toleransi terhadap oksigen. Masing-masing pengujian dilakukan dengan tiga kali ulangan.

Uji ketahanan terhadap salinitas dilakukan dengan memasukkan ikan pada akuarium (ukuran $40 \mathrm{~cm} \times 30$ $\mathrm{cm} \times 30 \mathrm{~cm}$; volume air: $30 \mathrm{~L})$ dengan media pemeliharaan bersalinitas $(25,20,15$, dan 10 ppt). Sementara itu, uji toleransi terhadap pH dilakukan dengan memasukkan ikan tambakan ke dalam akuarium (ukuran $40 \mathrm{~cm} \times 30 \mathrm{~cm} \times 30 \mathrm{~cm}$; volume air: $30 \mathrm{~L}$ ) dengan $\mathrm{pH}$ rendah (asam), yaitu pada $\mathrm{pH}$ sekitar 3, 4, dan 5, serta pH tinggi (basa), yaitu sekitar 8,9 , dan 10 . Media $\mathrm{pH}$ rendah dibuat dengan menambahkan cuka asam $\left(\mathrm{CH}_{3} \mathrm{COOH}\right)$ pada media pemeliharaan sampai diperoleh nilai $\mathrm{pH}$ yang diinginkan, sedangkan media $\mathrm{pH}$ tinggi dibuat melalui penambahan $\mathrm{NaOH}$.

Uji ketahanan terhadap suhu dilakukan dengan memasukkan ikan ke dalam media air (ukuran $30 \mathrm{~cm}$ $\times 20 \mathrm{~cm} \times 10 \mathrm{~cm}$; volume air: $5 \mathrm{~L}$ ) dengan suhu rendah (sekitar $10,15,20^{\circ} \mathrm{C}$ ) dan tinggi (sekitar 35 dan $40^{\circ} \mathrm{C}$ ). Suhu rendah diperoleh dengan mencampurkan es ke dalam media akuarium yang digunakan, sedangkan suhu tinggi diperoleh dengan menggunakan water bath yang telah diatur suhunya sebagai wadah uji. Sementara itu, pengujian ketahanan terhadap oksigen dilakukan dengan memasukkan ikan sebanyak 40 ekor ke dalam respirometer tertutup dan kedap udara yang dilengkapi DO meter dengan volume air sebanyak 10 liter. Selama pengamatan, tingkah laku dan kadar oksigen terlarut dalam respirometer diamati setiap lima menit untuk mengetahui respons ikan uji terhadap penurunan kadar oksigen terlarut akibat konsumsi oksigen ikan uji di dalam respirometer. Kadar oksigen terlarut yang menyebabkan awal gejala kematian ikan uji dicatat sebagai kadar oksigen terlarut letal. Dari keempat parameter uji ketahanan kualitas air yang dilakukan, data yang dikoleksi yaitu tingkah laku, waktu terjadinya kematian, dan sintasan ikan. Seluruh data dianalisis secara statistik menggunakan ANOVA dengan tingkat kepercayaan $95 \%$

\section{HASIL DAN BAHASAN}

\section{Uji Ketahanan Terhadap Salinitas}

Hasil pengujian ketahanan terhadap salinitas menunjukkan bahwa pada salinitas 25 ppt ikan memperlihatkan aktivitas renang yang tidak beraturan, warna tubuh yang semakin menghitam, melompatlompat tidak beraturan, dan kemudian posisi ikan terbalik tanpa pergerakan di dasar akuarium. Ikan mulai mengalami kematian pada menit ke-19 sampai akhirnya seluruh ikan uji mati pada menit ke-36. Pada salinitas $20 \mathrm{ppt}$, kematian ikan uji mulai terjadi pada menit ke-71 dan ikan secara keseluruhan mati pada menit ke-197. Sementara itu, pengujian pada salinitas 15 ppt menunjukkan awal terjadinya kematian mulai pada menit ke-508 dan diakhiri dengan kematian total seluruh ikan pada menit ke-1.218. Sedangkan pada salinitas 10 ppt, ikan tambakan dapat bertahan hidup sampai lebih dari 1.440 menit atau lebih dari 24 jam (Tabel 1 dan Gambar 1). Secara keseluruhan selama 24 jam pengamatan, sintasan ikan tambakan pada perlakuan salinitas 10 ppt $(100 \pm 0,0 \%$ berbeda nyata dengan perlakuan salinitas 15,20 , dan 25 ppt yang semua sintasannya $0 \pm 0,0 \%(P<0,05)$. 
Tabel 1. Tingkah laku, gejala klinis, dan waktu kematian ikan tambakan (Helostoma temminkii) pada pengujian salinitas

Table 1. Behaviour, clinical symptom, and mortality of kissing gouramy (Helostoma temminkii) under salinity treatments

\begin{tabular}{|c|c|c|c|c|}
\hline \multirow{2}{*}{$\begin{array}{l}\text { Waktu (menit) } \\
\text { Time (minutes) }\end{array}$} & \multicolumn{4}{|c|}{ Salinitas (Salinity) (ppt) } \\
\hline & 25 & 20 & 15 & 10 \\
\hline 1 & $\begin{array}{l}\text { Ikan megap-megap ke permukaan } \\
\text { dan melompat-lompat } \\
\text { Fish gasped on the surface and } \\
\text { jumps up and down }\end{array}$ & $\begin{array}{l}\text { Ikan megap-megap ke } \\
\text { permukaan dan } \\
\text { melompat-lompat } \\
\text { Fish gasped on the } \\
\text { surface and jumped up }\end{array}$ & Hidup (Alive) & Hidup (Alive) \\
\hline 2 & $\begin{array}{l}\text { Ikan berenang di atas permukaan } \\
\text { air dan terus melompat-lompat } \\
\text { Fish swam on the surface and kept } \\
\text { on jumping }\end{array}$ & Hidup (Alive) & Hidup (Alive) & Hidup (Alive) \\
\hline 3 & $\begin{array}{l}\text { Ikan mulai melemah } \\
\text { Fish became weaker }\end{array}$ & Hidup (Alive) & Hidup (Alive) & Hidup (Alive) \\
\hline 7 & $\begin{array}{l}\text { Ikan bergerak terbalik dan } \\
\text { berputar-putar } \\
\text { Fish moved upside down and } \\
\text { spinned around }\end{array}$ & Hidup (Alive) & Hidup (Alive) & Hidup (Alive) \\
\hline 10 & $\begin{array}{l}\text { Ikan diam dan sesekali bergerak } \\
\text { tidak beraturan } \\
\text { No movement and occasionally } \\
\text { moved irregularly }\end{array}$ & Hidup (Alive) & Hidup (Alive) & Hidup (Alive) \\
\hline 13 & $\begin{array}{l}\text { Ikan berwarna pucat } \\
\text { Fish became pale }\end{array}$ & Hidup (Alive ) & Hidup (Alive) & Hidup (Alive) \\
\hline 19 & $\begin{array}{l}\text { Ikan mengalami kematian } \\
\text { Fish were dying }\end{array}$ & Hidup (Alive) & Hidup (Alive) & Hidup (Alive) \\
\hline 22 & $\begin{array}{l}\text { Beberapa ikan mati } \\
\text { Some fish were dead }\end{array}$ & Hidup (Alive) & Hidup (Alive) & Hidup (Alive) \\
\hline 25 & $\begin{array}{l}\text { Beberapa ikan mati } \\
\text { Some fish were dead }\end{array}$ & Hidup (Alive) & Hidup (Alive) & Hidup (Alive) \\
\hline 28 & $\begin{array}{l}\text { Beberapa ikan mati } \\
\text { Some fish were dead }\end{array}$ & Hidup (Alive) & Hidup (Alive) & Hidup (Alive) \\
\hline 31 & $\begin{array}{l}\text { Setengah dari jumlah ikan uji mati } \\
\text { Half of tested fish were dead }\end{array}$ & Hidup (Alive) & Hidup (Alive) & Hidup (Alive) \\
\hline 34 & $\begin{array}{l}\text { Ikan mati semakin bertambah } \\
\text { The number of dead fish was } \\
\text { increased }\end{array}$ & Hidup (Alive) & Hidup (Alive) & Hidup (Alive) \\
\hline 36 & $\begin{array}{l}\text { Seluruh ikan uji mati } \\
\text { All of tested fish died }\end{array}$ & Hidup (Alive ) & Hidup (Alive) & Hidup (Alive) \\
\hline 71 & - & $\begin{array}{l}\text { Pertama kali ikan } \\
\text { mengalami kematian } \\
\text { The first time of } \\
\text { mortality occurred }\end{array}$ & Hidup (Alive) & Hidup (Alive) \\
\hline 145 & - & $\begin{array}{l}\text { Setengah dari jumlah } \\
\text { ikan uji mati } \\
\text { Half of tested fish were } \\
\text { dead }\end{array}$ & Hidup (Alive) & Hidup (Alive) \\
\hline 197 & - & $\begin{array}{l}\text { Seluruh ikan mati } \\
\text { All of tested fish died }\end{array}$ & Hidup (Alive) & Hidup (Alive) \\
\hline 508 & - & - & $\begin{array}{l}\text { Pertama kali ikan mengalami } \\
\text { kematian } \\
\text { The first time of mortality occurred }\end{array}$ & Hidup (Alive) \\
\hline 624 & - & - & $\begin{array}{l}\text { Setengah dari jumlah ikan uji mati } \\
\text { Half of tested fish were dead }\end{array}$ & Hidup (Alive) \\
\hline 1218 & - & - & $\begin{array}{l}\text { Seluruh ikan mati } \\
\text { All of tested fish died }\end{array}$ & Hidup (Alive) \\
\hline 1440 & - & - & - & Hidup (Alive) \\
\hline
\end{tabular}




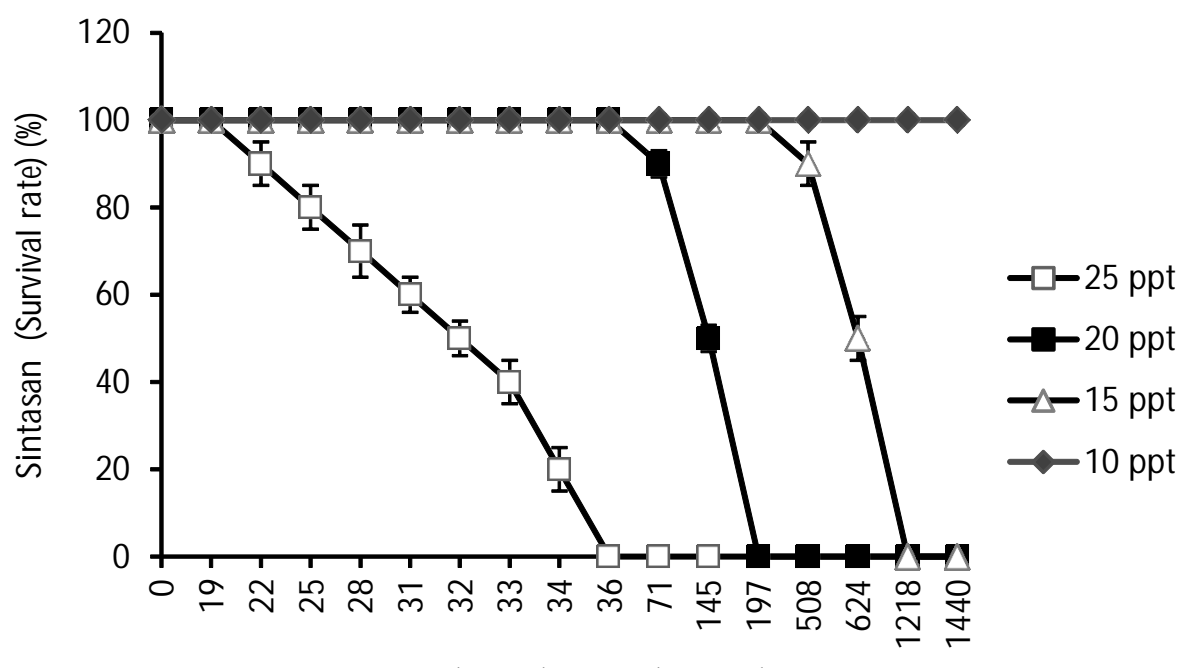

Waktu (menit) / Time (minutes)

Gambar 1. Sintasan ikan tambakan (Helostoma temminkii) pada pengujian salinitas.

Figure 1. Survival rate of kissing gouramy (Helostoma temminkii) treated under different salinities.

Ikan tambakan dapat menoleransi salinitas $10 \mathrm{ppt}$ sampai lebih dari 24 jam. Akan tetapi, paparan salinitas di atas 10 ppt berpengaruh negatif pada aktivitas dan sintasannya, karena menyebabkan kematian. Penelitian terdahulu juga melaporkan hal yang sama tentang pengaruh negatif paparan salinitas di luar batas toleransi pada beberapa spesies ikan (Sawant et al., 2001; Bonis ${ }^{3}$ awska et al., 2014; Gutierre et al., 2016; Souza-Bastos et al., 2016; Tietze, 2016). Hal tersebut terjadi akibat dari penambahan salinitas menyebabkan terganggunya keseimbangan osmotik karena perbedaan tekanan osmotik antara tubuh dengan lingkungannya berada di luar kapasitas osmoregulatori dari ikan tersebut (Limburg \& Ross, 1995; Souza-Bastos et al., 2016).

\section{Uji Ketahanan Terhadap pH}

Hasil pengujian ketahanan terhadap $\mathrm{pH}$ menunjukkan bahwa pada pH 3, ikan tambakan hanya mampu bertahan hidup selama kurang dari 14 menit. Sementara itu pada pH 4, ikan tambakan mulai mengalami kematian pada menit ke-5 sampai akhirnya kematian total terjadi pada menit ke-96. Sedangkan pada pH 5, ikan tambakan dapat bertahan hidup sampai lebih dari 24 jam.

Saat pengujian di pH 8 dan 9, ikan tambakan dapat bertahan hidup, berenang dengan normal, tidak menunjukkan gejala klinis, dan tidak mengalami kematian. Akan tetapi pada uji ketahanan di pH 10, ikan tambakan mulai mengalami penurunan persentase sintasan pada menit ke-221, sampai akhirnya seluruh ikan mati pada menit ke-757 (Tabel 2 dan Gambar 2). Secara keseluruhan selama 24 jam pengamatan, sintasan ikan tambakan pada perlakuan pH 5, 8, dan 9 (100 $\pm 0,0 \%$ berbeda nyata dengan perlakuan $\mathrm{pH} 3$, 4, dan 10 yang menghasilkan sintasan $0 \pm 0,0 \%$ $(P<0,05)$.

Hasil percobaan paparan pH menunjukkan bahwa pH asam dan basa berpengaruh terhadap sintasan ikan tambakan. Paparan pH asam dan basa mengharuskan ikan untuk menyesuaikan diri dengan lingkungannya untuk bertahan hidup. Akan tetapi, nilai pH di luar ambang batas mengakibatkan kematian pada ikan tambakan.

Berdasarkan penelitian terdahulu pada ikan nila, pH 5-8 masih dapat ditoleransi, namun terjadi penurunan tingkat pertumbuhan pada pH 5 (Ath-thar et al., 2010). Sedangkan sintasan dan kandungan plasma sodium pada ikan nila semakin menurun akibat paparan pH asam (Ito \& Yada, 1997). Sementara itu, pada ikan fathead minnow, perlakuan $\mathrm{pH}$ rendah sampai 4,5 tidak menyebabkan kematian pada ikan. Akan tetapi paparan $\mathrm{pH}$ rendah menyebabkan tingkah laku ikan menjadi abnormal serta semakin rendahnya fekunditas dan daya tetas telur (Mount, 1973). Dalam perco baan lainnya, ikan perch dapat hidup pada pH 10, namun mengalami kematian di pH 11 (Beklioglu \& Moss, 1995).

Sedangkan beberapa penelitian pada ikan rainbow trout menunjukkan bahwaikan ini dapat bertahan hidup pada kondisi pH basa (8-10) dalam waktu yang cukup 
Tabel 2. Tingkah laku, gejala klinis, dan waktu kematian ikan tambakan (Helostoma temminkii) pada pengujian $\mathrm{pH}$

Table 2. Behaviour, clinical symptoms, and mortality of kissing gouramy (Helostoma temminkii) treated under different $\mathrm{pH}$

\begin{tabular}{|c|c|c|c|c|c|c|}
\hline \multirow{2}{*}{$\begin{array}{l}\text { Waktu (menit) } \\
\text { Time (minutes) }\end{array}$} & \multicolumn{6}{|c|}{ pH } \\
\hline & 3 & 4 & 5 & 8 & 9 & 10 \\
\hline 1 & $\begin{array}{l}\text { Mengeluarkan buih } \\
\text { Fish released the foam }\end{array}$ & $\begin{array}{l}\text { Mengeluarkan buih } \\
\text { Fish released the } \\
\text { foam }\end{array}$ & $\begin{array}{l}\text { Hidup } \\
\text { Alive }\end{array}$ & $\begin{array}{l}\text { Ikan } \\
\text { bergerak } \\
\text { normal } \\
\text { Fish } \\
\text { moved } \\
\text { normally }\end{array}$ & $\begin{array}{l}\text { Ikan } \\
\text { bergerak } \\
\text { normal } \\
\text { Fish moved } \\
\text { normally }\end{array}$ & $\begin{array}{l}\text { Ikan bergerak } \\
\text { normal } \\
\text { Fish moved } \\
\text { normally }\end{array}$ \\
\hline 2 & $\begin{array}{l}\text { Warna badan berubah } \\
\text { putih, lendir mengelupas } \\
\text { Body color turned white, } \\
\text { mucus peeled }\end{array}$ & $\begin{array}{l}\text { Warna badan } \\
\text { berubah putih, } \\
\text { lendir mengelupas } \\
\text { Body color turns } \\
\text { white, mucus } \\
\text { peeled }\end{array}$ & $\begin{array}{l}\text { Hidup } \\
\text { Alive }\end{array}$ & $\begin{array}{l}\text { Ikan } \\
\text { bergerak } \\
\text { normal } \\
\text { Fish } \\
\text { moved } \\
\text { normally }\end{array}$ & $\begin{array}{l}\text { Ikan } \\
\text { bergerak } \\
\text { normal } \\
\text { Fish moved } \\
\text { normally }\end{array}$ & $\begin{array}{l}\text { Ikan berwarna } \\
\text { pucat } \\
\text { Fish became } \\
\text { pale }\end{array}$ \\
\hline 3 & $\begin{array}{l}\text { Ikan mulai melemah dan } \\
\text { sulit bergerak } \\
\text { Fish began to weaken and } \\
\text { difficult to move }\end{array}$ & $\begin{array}{l}\text { Ikan mulai } \\
\text { melemah dan sulit } \\
\text { bergerak } \\
\text { Fish began to } \\
\text { weaken and } \\
\text { difficult to move }\end{array}$ & $\begin{array}{l}\text { Hidup } \\
\text { Alive }\end{array}$ & $\begin{array}{l}\text { Hidup } \\
\text { Alive }\end{array}$ & $\begin{array}{l}\text { Hidup } \\
\text { Alive }\end{array}$ & $\begin{array}{l}\text { Ikan } \\
\text { melompat- } \\
\text { lompat } \\
\text { Fish jumped } \\
\text { up and down }\end{array}$ \\
\hline 4 & $\begin{array}{l}\text { Warna mata putih, air } \\
\text { berbusa } \\
\text { Eye color turned white, } \\
\text { foamy water }\end{array}$ & $\begin{array}{l}\text { Warna mata putih, } \\
\text { air berbusa } \\
\text { Eye color turned } \\
\text { white, foamy water }\end{array}$ & $\begin{array}{l}\text { Hidup } \\
\text { Alive }\end{array}$ & & & \\
\hline 5 & $\begin{array}{l}\text { Gerakan tidak beraturan } \\
\text { dan melengkung } \\
\text { Irregular and curved } \\
\text { movements }\end{array}$ & $\begin{array}{l}\text { Pertama kali terjadi } \\
\text { kematian } \\
\text { The first time of } \\
\text { mortality occurred }\end{array}$ & $\begin{array}{l}\text { Hidup } \\
\text { Alive }\end{array}$ & $\begin{array}{l}\text { Hidup } \\
\text { Alive }\end{array}$ & $\begin{array}{l}\text { Hidup } \\
\text { Alive }\end{array}$ & $\begin{array}{l}\text { Lendir } \\
\text { mengelupas, } \\
\text { sirip } \\
\text { menghitam } \\
\text { Mucus peeled, } \\
\text { blackened fins }\end{array}$ \\
\hline 6 & $\begin{array}{l}\text { Ikan tidak mampu } \\
\text { berenang } \\
\text { Fish were have difficulty to } \\
\text { swim }\end{array}$ & $\begin{array}{l}\text { Ikan lainnya masih } \\
\text { hidup } \\
\text { The rest of fish were } \\
\text { still alive }\end{array}$ & $\begin{array}{l}\text { Hidup } \\
\text { Alive }\end{array}$ & & & \\
\hline 7 & $\begin{array}{l}\text { Ikan hanya dapat } \\
\text { menggerak-gerakan sirip } \\
\text { dada } \\
\text { Fish could only move their } \\
\text { pectoral fins }\end{array}$ & $\begin{array}{l}\text { Ikan lainnya masih } \\
\text { hidup } \\
\text { The rest of fish were } \\
\text { still alive }\end{array}$ & $\begin{array}{l}\text { Hidup } \\
\text { Alive }\end{array}$ & & & \\
\hline 8 & $\begin{array}{l}\text { Gerakan refleks tidak } \\
\text { beraturan } \\
\text { Irregular reflex movement }\end{array}$ & $\begin{array}{l}\text { Ikan lainnya masih } \\
\text { hidup } \\
\text { The rest of fish were } \\
\text { still alive }\end{array}$ & $\begin{array}{l}\text { Hidup } \\
\text { Alive }\end{array}$ & & & \\
\hline 9 & $\begin{array}{l}\text { Ikan mengeluarkan } \\
\text { gelembung dan mulai } \\
\text { terjadi kematian } \\
\text { Fish released bubbles and } \\
\text { mortality occurred }\end{array}$ & $\begin{array}{l}\text { Ikan lainnya masih } \\
\text { hidup } \\
\text { The rest of fish were } \\
\text { still alive }\end{array}$ & $\begin{array}{l}\text { Hidup } \\
\text { Alive }\end{array}$ & $\begin{array}{l}\text { Hidup } \\
\text { Alive }\end{array}$ & $\begin{array}{l}\text { Hidup } \\
\text { Alive }\end{array}$ & $\begin{array}{l}\text { Ikan berenang } \\
\text { berputar-putar } \\
\text { Fish swim } \\
\text { swirl }\end{array}$ \\
\hline 12 & $\begin{array}{l}\text { Setengah dari jumlah ikan } \\
\text { uji mati } \\
\text { Half of tested fish were } \\
\text { dead }\end{array}$ & $\begin{array}{l}\text { Ikan lainnya masih } \\
\text { hidup } \\
\text { The rest of fish were } \\
\text { still alive }\end{array}$ & $\begin{array}{l}\text { Hidup } \\
\text { Alive }\end{array}$ & & & \\
\hline
\end{tabular}


Tabel 2. Lanjutan

Table 2. Continued

\begin{tabular}{|c|c|c|c|c|c|c|}
\hline \multirow{2}{*}{$\begin{array}{l}\text { Waktu (menit) } \\
\text { Time (minutes) }\end{array}$} & \multicolumn{6}{|c|}{ pH } \\
\hline & 3 & 4 & 5 & 8 & 9 & 10 \\
\hline 14 & $\begin{array}{l}\text { Seluruh ikan uji mati } \\
\text { All of tested fish died }\end{array}$ & $\begin{array}{l}\text { Ikan lainnya masih } \\
\text { hidup } \\
\text { The rest of fish were } \\
\text { still alive }\end{array}$ & $\begin{array}{l}\text { Hidup } \\
\text { Alive }\end{array}$ & & & \\
\hline 17 & - & $\begin{array}{l}\text { Beberapa ikan mati } \\
\text { Several fish died }\end{array}$ & $\begin{array}{l}\text { Hidup } \\
\text { Alive }\end{array}$ & & & \\
\hline 20 & & & & & & $\begin{array}{l}\text { Ikan berenang } \\
\text { di sudut } \\
\text { bawah } \\
\text { akuarium } \\
\text { Fish swam at } \\
\text { in the bottom } \\
\text { corner of the } \\
\text { aquarium }\end{array}$ \\
\hline 37 & - & $\begin{array}{l}\text { Setengah dari } \\
\text { jumlah ikan mati } \\
\text { Half of tested fish } \\
\text { were dead }\end{array}$ & $\begin{array}{l}\text { Hidup } \\
\text { Alive }\end{array}$ & $\begin{array}{l}\text { Hidup } \\
\text { Alive }\end{array}$ & $\begin{array}{l}\text { Hidup } \\
\text { Alive }\end{array}$ & \\
\hline 60 & & & & & & $\begin{array}{l}\text { Ikan diam, } \\
\text { sesekali } \\
\text { mengambil } \\
\text { oksigen ke } \\
\text { permukaan } \\
\text { No movement, } \\
\text { occasionally } \\
\text { taking oxygen } \\
\text { to the surface }\end{array}$ \\
\hline 96 & - & $\begin{array}{l}\text { Seluruh ikan mati } \\
\text { All of tested fish } \\
\text { died }\end{array}$ & $\begin{array}{l}\text { Hidup } \\
\text { Alive }\end{array}$ & & & \\
\hline 120 & & & & & & $\begin{array}{l}\text { Ikan melemah } \\
\text { dan hanya } \\
\text { bergerak } \\
\text { mengambil } \\
\text { oksigen } \\
\text { Fish weaken } \\
\text { and only } \\
\text { moved to take } \\
\text { oxygen }\end{array}$ \\
\hline 221 & & & & & & $\begin{array}{l}\text { Ikan } \\
\text { mengalami } \\
\text { kematian }\end{array}$ \\
\hline 757 & & & & & & $\begin{array}{l}\text { Seluruh ikan } \\
\text { mati } \\
\text { All of tested } \\
\text { fish died }\end{array}$ \\
\hline 1.440 & - & - & $\begin{array}{l}\text { Seluruh } \\
\text { ikan hidup } \\
\text { All of } \\
\text { tested fish } \\
\text { were alive }\end{array}$ & $\begin{array}{l}\text { Seluruh } \\
\text { ikan hidup } \\
\text { All of } \\
\text { tested fish } \\
\text { were alive }\end{array}$ & $\begin{array}{l}\text { Seluruh } \\
\text { ikan hidup } \\
\text { All of } \\
\text { tested fish } \\
\text { were alive }\end{array}$ & \\
\hline
\end{tabular}




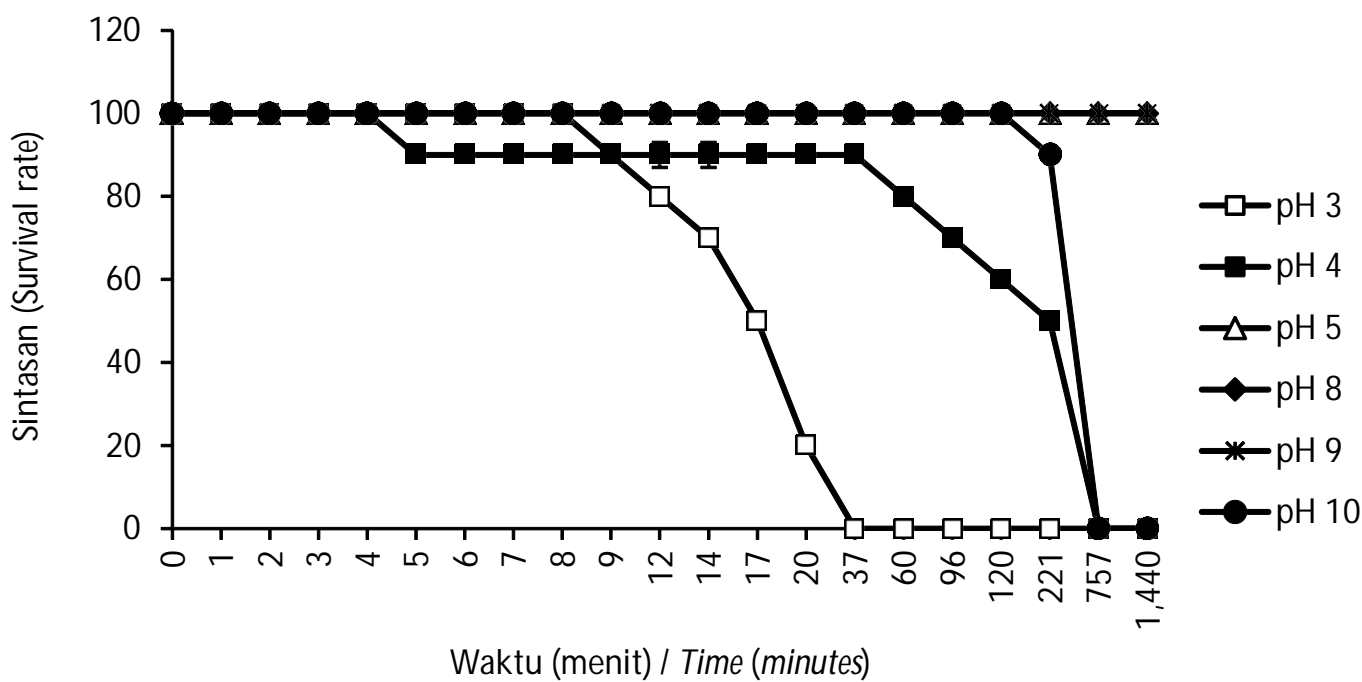

Gambar 2. Sintasan ikan tambakan (Helostoma temminkii) pada pengujian $\mathrm{pH}$.

Figure 2. Survival rate of kissing gouramy (Helostoma temminkii) treated under different pH levels.

lama. Kemampuan untuk bertahan hidup pada ikan tambakan dan ikan lainnya yang telah diteliti disebabkan adanya proses penyesuaian pada keseimbangan asam-basa dalam tubuh, pertukaran ion dalam sistem pernapasan, serta ekskresi dan produksi amonia (Wilkie et al., 1996; Wilson et al., 1998; Ip et al., 2001).

\section{Uji Ketahanan Terhadap Suhu}

Berdasarkan hasil uji ketahanan terhadap suhu, ikan tambakan mampu bertahan hidup dan beraktivitas secara normal pada suhu $20^{\circ} \mathrm{C}$. Akan tetapi, suhu $15^{\circ} \mathrm{C}$ atau lebih rendah bersifat letal bagi ikan tambakan. Sementara itu pada suhu tinggi, ikan tambakan mampu hidup pada suhu $35^{\circ} \mathrm{C}$ dengan sintasan $100 \%$ namun mengalami kematian pada suhu $40^{\circ} \mathrm{C}$ dengan jumlah kematian total pada menit ke-5 (Tabel 3 dan Gambar 3). Secara keseluruhan selama 24 jam pengamatan, sintasan ikan tambakan pada perlakuan 20 dan $35^{\circ} \mathrm{C}$ (100 $\pm 0,0 \%$ berbeda nyata dengan perlakuan suhu 10,15 , dan $40^{\circ} \mathrm{C}$ yang menghasilkan sintasan $0 \pm 0,0 \%$ atau mengalami kematian total $(P<0,05)$.

Pada penelitian ini, paparan suhu di luar kisaran optimal pada memiliki hubungan negatif terhadap aktivitas dan sintasan ikan tambakan. Hal ini juga diperkuat dari pernyataan beberapa orang yang meneliti tentang toleransi suhu pada beberapa jenis ikan, yaitu bahwa suhu rendah dan tinggi yang melebihi kisaran normal bagi spesies ikan tersebut dapat menyebabkan kematian (Webb, 2008; Schofield et al., 2011; Gutierre et al., 2016). Penelitian mengenai pengaruh negatif dan positif suhu rendah dan tinggi pada ikan telah banyak dilakukan pada beberapa spesies (Pepin, 1991; Hart \& Purser, 1995; Hamel et al., 1997; Gutierre et al., 2016; Tamkeen et al., 2016). Berdasarkan informasi dari penelitian ini, suhu pemeliharaan $40^{\circ} \mathrm{C}$ dan $15^{\circ} \mathrm{C}$ atau lebih rendah lagi dapat dikatakan sebagai tingkat letal bagi ikan tambakan.

\section{Uji Ketahanan Terhadap Oksigen}

Hasil uji tingkat oksigen letal menunjukkan bahwa ikan tambakan hanya bertahan selama 30 sampai 38 menit dengan adanya penurunan tingkat oksigen terlarut yang drastis di dalam wadah pemeliharaan. Ikan tambakan mulai mengalami kematian pada menit ke-30 saat oksigen terlarut menjadi 1,8 mg/L. Pada menit ke-35, sebanyak 50\%ikan mengalami kematian, sampai akhirnya seluruh ikan mati pada menit ke-38 seluruh ikan uji mati dengan kandungan oksigen terlarut terakhir dalam air sebesar 1,4 mg/L (Tabel 4). Hasil penelitian juga menunjukkan bahwa oksigen terlarut di bawah $3 \mathrm{mg} / \mathrm{L}$ menyebabkan aktivitas ikan terganggu dan pada akhirnya menyebabkan kematian seluruh ikan apabila tingkat oksigen terlarut terus mengalami penurunan.

Tingkat oksigen terlarut letal bagi ikan berbedabeda, tergantung spesies dan tingkat adaptasinya. Beberapa studi telah dilakukan untuk mengamati tingkat oksigen terlarut letal pada beberapa spesies ikan (Itazawa, 1959; Kutty \& Mohamed, 1975; Randall, 1982). Informasi mengenai tingkat oksigen terlarut yang bersifat letal bagi ikan tambakan masih jarang ditemui. Dalam percobaan ini, aktivitas ikan menurun 
Tabel 3. Tingkah laku, gejala klinis, dan waktu kematian ikan tambakan (Helostoma temminkii) pada pengujian suhu

Table 3. Behaviour, clinical symptoms, and mortality time of kissing gouramy (Helostoma temminkii) treated under different water temperatures

\begin{tabular}{|c|c|c|c|c|c|}
\hline \multirow{2}{*}{$\begin{array}{l}\text { Waktu (menit) } \\
\text { Time (minutes) }\end{array}$} & \multicolumn{5}{|c|}{ Suhu (Temperature) $\left({ }^{\circ} \mathrm{C}\right)$} \\
\hline & 10 & 15 & 20 & 35 & 40 \\
\hline 1 & $\begin{array}{l}\text { Ikan bergerak secara } \\
\text { tidak beraturan } \\
\text { Fish moved } \\
\text { irregularly }\end{array}$ & $\begin{array}{l}\text { Ikan bergerak secara } \\
\text { tidak beraturan } \\
\text { Fish move } \\
\text { irregularly }\end{array}$ & $\begin{array}{l}\text { Bergerak } \\
\text { normal } \\
\text { Normal } \\
\text { movement }\end{array}$ & $\begin{array}{l}\text { Bergerak } \\
\text { normal } \\
\text { Normal } \\
\text { movement }\end{array}$ & $\begin{array}{l}\text { Ikan bergerak } \\
\text { tidak beraturan } \\
\text { Fish move } \\
\text { irregularly }\end{array}$ \\
\hline 2 & $\begin{array}{l}\text { I kan tidak mampu } \\
\text { bergerak } \\
\text { Fish could } \\
\text { not move }\end{array}$ & $\begin{array}{l}\text { Ikan tidak mampu } \\
\text { bergerak } \\
\text { Fish could } \\
\text { not move }\end{array}$ & $\begin{array}{l}\text { Bergerak } \\
\text { normal } \\
\text { Normal } \\
\text { movement }\end{array}$ & $\begin{array}{l}\text { Bergerak } \\
\text { normal } \\
\text { Normal } \\
\text { movement }\end{array}$ & $\begin{array}{l}\text { Melompat } \\
\text { ke permukaan } \\
\text { Jumped to the } \\
\text { surface }\end{array}$ \\
\hline 3 & $\begin{array}{l}\text { Seluruh ikan mati } \\
\text { All of tested fish died }\end{array}$ & $\begin{array}{l}\text { Seluruh ikan mati } \\
\text { All of tested fish died }\end{array}$ & $\begin{array}{l}\text { Bergerak } \\
\text { normal } \\
\text { Normal } \\
\text { movement }\end{array}$ & $\begin{array}{l}\text { Bergerak } \\
\text { normal } \\
\text { Normal } \\
\text { movement }\end{array}$ & $\begin{array}{l}\text { Mulai terjadi } \\
\text { kematian } \\
\text { Mortality } \\
\text { occurred }\end{array}$ \\
\hline 4 & & & $\begin{array}{l}\text { Bergerak } \\
\text { normal } \\
\text { Normal } \\
\text { movement }\end{array}$ & $\begin{array}{l}\text { Bergerak } \\
\text { normal } \\
\text { Normal } \\
\text { movement }\end{array}$ & $\begin{array}{l}\text { Kematian ikan } \\
\text { bertambah } \\
\text { M ortality } \\
\text { increase }\end{array}$ \\
\hline 5 & & & $\begin{array}{l}\text { Bergerak } \\
\text { normal } \\
\text { Normal } \\
\text { movement }\end{array}$ & $\begin{array}{l}\text { Bergerak } \\
\text { normal } \\
\text { Normal } \\
\text { movement }\end{array}$ & $\begin{array}{l}\text { Seluruh ikan } \\
\text { mati } \\
\text { All of tested fish } \\
\text { died }\end{array}$ \\
\hline 1.44 & & & $\begin{array}{l}\text { Seluruh } \\
\text { ikan hidup } \\
\text { The whole } \\
\text { fish is alive }\end{array}$ & $\begin{array}{l}\text { Seluruh ikan } \\
\text { hidup } \\
\text { The whole } \\
\text { fish is alive }\end{array}$ & \\
\hline
\end{tabular}

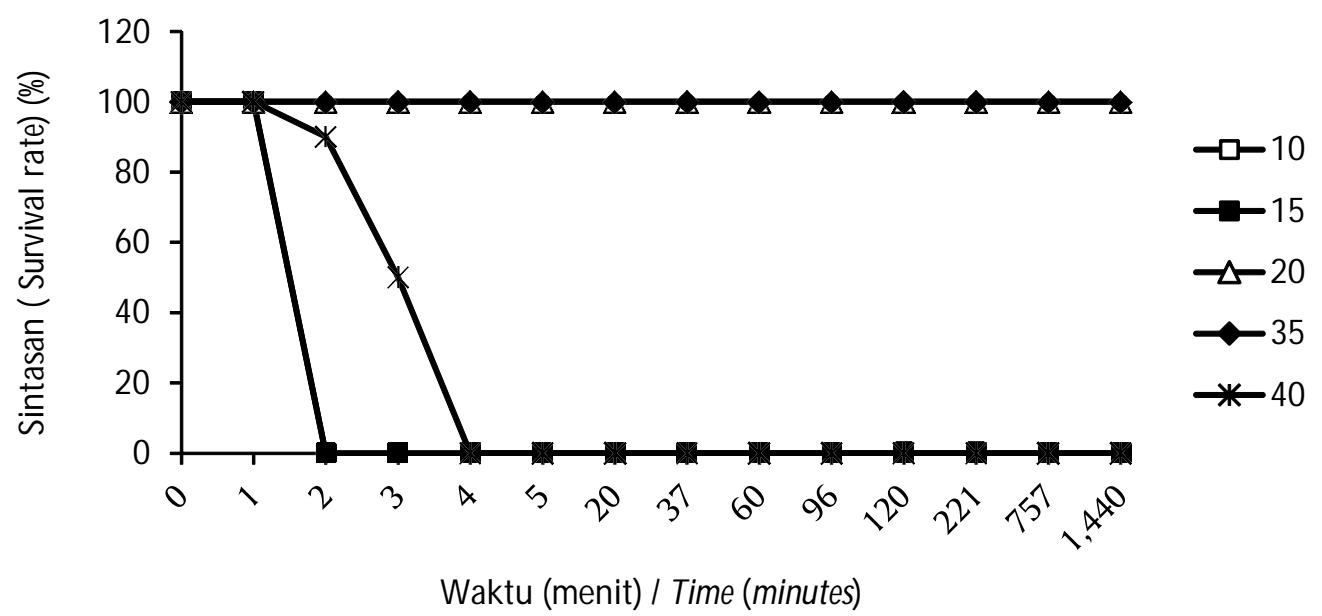

Gambar 3. Sintasan ikan tambakan (Helostoma temminkii) pada pengujian suhu.

Figure 3. Survival rate of kissing gouramy (Helostoma temminkii) treated under different water temperatures. 
Tabel 4. Tingkah laku, gejala klinis, dan waktu kematian ikan tambakan (Helostoma temminkii) pada pengujian tingkat oksigen letal

Table 4. Behaviour, clinical symptoms, and mortality of kissing gouramy (Helostoma temminkii) treated under various levels of dissolved oxygen

\begin{tabular}{|c|c|c|}
\hline $\begin{array}{l}\text { Waktu (menit) } \\
\text { Time (minutes) }\end{array}$ & Gejala klinis (Clinical symptoms ) & $\begin{array}{l}\text { Oksigen terlarut } \\
\text { Dissolved oxygen } \\
\text { (mg/L) }\end{array}$ \\
\hline 1 & $\begin{array}{l}\text { Ikan bergerak tenang } \\
\text { Fish move calmly }\end{array}$ & 6.4 \\
\hline 5 & $\begin{array}{l}\text { Ikan mulai bergerak gelisah } \\
\text { Fish began to move uneasily }\end{array}$ & 5.7 \\
\hline 10 & $\begin{array}{l}\text { Ikan mulai bergerak ke permukaan } \\
\text { Fish began to move to the surface }\end{array}$ & 4.6 \\
\hline 15 & $\begin{array}{l}\text { Ikan semakin lincah bergerak ke permukaan } \\
\text { Fish increase their agility to move to the surface }\end{array}$ & 3.6 \\
\hline 20 & $\begin{array}{l}\text { Sebagian ikan mulai melemah dan bergerak di dasar } \\
\text { Some fish began to weaken and move at the bottom }\end{array}$ & 2.9 \\
\hline 25 & $\begin{array}{l}\text { Seluruh ikan mulai melemah dan bergerak di dasar } \\
\text { All fish began to weaken and move at the bottom }\end{array}$ & 2.3 \\
\hline 30 & $\begin{array}{l}\text { Ikan bergerak refleks dari dasar ke permukaan, mulai terjadi kematian } \\
\text { Fish moved reflexly from bottom to surface, mortality occurred }\end{array}$ & 1.8 \\
\hline 35 & $\begin{array}{l}\text { Ikan sulit bergerak dan megap-megap di dasar, setengah dari jumlah ikan mati } \\
\text { Fish have difficulty to move and gasped at the bottom, half of tested fish were dead }\end{array}$ & 1.5 \\
\hline 38 & $\begin{array}{l}\text { Seluruh ikan mati } \\
\text { All of tested fish died }\end{array}$ & 1.4 \\
\hline
\end{tabular}

sejalan dengan penurunan oksigen terlarut karena terjadi hipoksia, yang pada akhirnya menyebabkan kematian (Dalla Via et al., 1998). Pada tingkat akut, kekurangan oksigen akan memengaruhi pertumbuhan dan sintasan ikan (Smith \& Able, 2003). Menurut informasi dari penelitian ini, ikan tambakan harus dipertahankan di atas tingkat oksigen letal untuk mengoptimalkan pertumbuhan dan sintasannya pada lingkungan budidaya. Domenici et al. (2013) menyatakan bahwa sangat penting untuk memahami toleransi hipoksia spesies ikan budidaya serta respons tingkah lakunya. Selain itu, Flint et al. (2015) berpendapat bahwa pengaruh dari hipoksia pada kemampuan ikan untuk mencegah penyakit, parasit dan buruknya kualitas air juga penting untuk dipelajari guna memahami efek sebenarnya dari hipoksia pada spesies ikan yang diteliti.

\section{KESIMPULAN}

Berdasarkan data penelitian, ikan tambakan dapat bertahan hidup dan beraktivitas secara normal pada kisaran salinitas $\leq 10 \mathrm{ppt}$, pH 5-9, suhu $20-35^{\circ} \mathrm{C}$, dan kandungan oksigen terlarut $>3 \mathrm{mg} / \mathrm{L}$.

\section{UCAPAN TERIMA KASIH}

Penulis mengucapkan terima kasih kepada Ir. Anang Hari Kristanto, M.Sc., Ph.D., Drs. Jojo Subagja, M.Si., Wahyulia Cahyanti, S.Pi., Fera Permata Putri, S.Pi., Deni Irawan, dan Heppy Aprillistianto atas kontribusinya selama penelitian berlangsung. Penelitian ini merupakan bagian dari penelitian yang dibiayai oleh DIPA BPPBAT tahun 2016.

\section{DAFTAR PUSTAKA}

Ath-thar, M.H.F. \& Gustiano, R. (2010). Performa ikan nila BEST dalam media salinitas. Dalam: Sudradjat, A., Rachmansyah, Hanafi, A., Azwar, Z.I., Imron, Kristanto, A.H., Chumaidi \& Insan, I. (Eds.), Prosiding Forum Inovasi Teknologi Akuakultur (hlm. 493-499). Pusat Penelitian dan Pengembangan Perikanan Budidaya, Jakarta.

Ath-thar, M.H.F., Prakoso, V.A., Arifin, 0.Z., \& Gustiano, R. (2010). Performa pertumbuhan ikan nila BEST pada berbagai media pH. Dalam Tim Penyusun Prosiding Seminar Nasional Biologi 2010 (Eds.), Prosiding Seminar Nasional Biologi, Universi- 
tas Gadjah Mada (hlm. 1085-1089). Fakultas Biologi Universitas Gadjah Mada, Yogyakarta.

Ayala, M.D., Martínez, J.M., Hernandez-Urcera, J., \& Cal, R. (2016). Effect of the early temperature on the growth of larvae and postlarvae turbot, Scophthalmus maximus L.: muscle structural and ultrastructural study. Fish Physiology and Biochemistry, 42, 1027.

Barton, B.A. \& Iwama, G.K. (1991). Physiological changes in fish from stress in aquaculture with emphasis on the response and effects of corticosteroids. Annual Review of Fish Diseases, 1, 3-26.

Beklioglu, M. \& Moss, B. (1995). The impact of pH on interactions among phytoplankton algae, zooplankton and perch (Perca fluviatilis) in a shallow, fertile lake. Freshwater Biology, 33, 497-509.

Bonis ${ }^{3} a w s k a$, M., Tanski, A., Szulc, J., Machula, S., \& Formicki, K. (2014). Water salinity effects on embryogenesis of the lesser sandeel, Ammodytes tobianus (Linnaeus, 1758). Central European Journal of Biology, 9(11), 1068-1077.

Dalla Via, D., van den Thillart, G., Cattani, 0., \& Cortesi, P. (1998). Behavioural responses and biochemical correlates in Solea solea to gradual hypoxic exposure. Canadian Journal of Zoology, 76, 2108-2113.

Domenici, P., Herbert, N.A., Lefrançois, C., Steffensen, J.F., \& McKenzie, D.J. (2013). The Effect of Hypoxia on Fish Swimming Performance and Behaviour. In: Palstra, A.P. \& Planas J.V. (eds.). Swimming Physiology of Fish. Springer-Verlag Berlin Heidelberg, p. 129-159.

Efriyeldi \& Pulungan, C.P. (1995). Hubungan panjang berat dan fekunditas ikan tambakan (Helostoma temminckii) dari perairan sekitar Taratak Buluh. Pusat Penelitian Universitas Riau, Pekanbaru, 26 pp (unpublished).

Flint, N., Crossland, M.R., \& Pearson, R.G. (2015). Sublethal effects of fluctuating hypoxia on juvenile tropical Australian freshwater fish. Marine and Freshwater Research, 66, 293-304.

Gutierre, S.M.M., Schofield, P.J., \& Prodocimo, V. (2016). Salinity and temperature tolerance of an emergent alien species, the Amazon fish Astronotus ocellatus. Hydrobiologia, $11 \mathrm{pp}$.

Hart, P.R. \& Purser, G. (1995). Effects of salinity and temperature on eggs and yolk sac larvae of the greenback flounder (Rhombosolea tapirina Günther, 1862). Aquaculture, 136, 221-230.

Hamel, P., Magnan, P., East, P., Lapointe, M., \& Laurendeau, P. (1997). Comparison of different models to predict the in situ embryonic develop- mental rate of fish: with special reference to white sucker (Catostomus commersoni). Canadian Journal of Fisheries and Aquatic Sciences, 54, 190- 197.

Itazawa, Y. (1959). Gas content of the blood in response tothat of medium water in fish. II. Comparison of the response in several species. Bulletin of Japan Society Fisheries, 25, 301-306.

Ito, F. \& Yada, T. (1997). Differences in tolerance to acidic environments between two species of tilapia, Oreochromis niloticus and 0. M ossambicus. Bulletin National Resources Institute of Fisheries Science, 9, 11-18.

Ip, Y.K., Chew, S.F., \& Randall, D.J. (2001). Ammonia toxicity, tolerance and excretion. Fish Physiology, vol. 20. Academic Press, London, p. 109-148.

Kutty, M.N. \& Mohamed, M.P. (1975). Metabolic adaptations of mullets Rhinomugil corsula (Hamilton) with special reference to energy utilization. Aquaculture, 5, 253-270.

Limburg, K.E. \& Ross, R.M. (1995). Growth and mortality rates of larval american shad, Alosa sapidissima, at different salinities. Estuaries, 2, 335340.

Lorenz, T., Riccobono, S.A., \& Smith, P. (2015). Effects of salinity on the survival and aggression of the invasive Rio Grande cichlid (Herichthys cyanoguttatus). Marine and Freshwater Behaviour and Physiology, 2015, 8 pp.

Mount, D.I. (1973). Chronic effect of low pH on fathead minnow survival, growth and reproduction. U.S. Environmental Protection Agency Papers. Paper 14.

Pepin, P. (1991). Effect of temperature and size on development, mortality, and survival rates of the pelagic early life history stages of marine fish. Canadian Journal of Fisheries and Aquatic Sciences, 48, 503-518.

Randall, D. (1982). The Control of respiration and circulation in fish during exercise and hypoxia. Journal of Experimental Biology, 100, 275-288.

Sawant, M.S., Zhang, S., \& Li, L. (2001). Effect of salinity on development of zebrafish, Brachydanio rerio. Current Science, 81, 1347-1350.

Scott, D.M., Lucas, M.C., \& Wilson, R.W. (2005). The effect of high $\mathrm{pH}$ on ion balance, nitrogen excretion and behaviour in freshwater fish from an eutrophic lake: A laboratory and field study. Aquatic Toxicology, 73, 31-43.

Schofield, P.J., Peterson, M.S., Lowe, M.R., BrownPeterson, N.J., \& Slack, W.T. (2011). Survival, growth and reproduction of non-indigenous Nile tilapia, Oreochromis niloticus (Linnaeus 1758). I. 
Physiological capabilities in various temperatures and salinities. Marine and Freshwater Research, 62, 439-449.

Selye, H. (1974). Stress without distress. McClelland Stewart, Toronto, $171 \mathrm{pp}$.

Smith, K.J. \& Able, K.W. (2003). Dissolved oxygen dynamics in salt marsh pools and its potential impacts on fish assemblages. Marine Ecology Progress Series, 258, 223-232.

Souza-Bastos, L.R., Bastos, L.P., Carneiro, P.C.F., \& Freire, C.A. (2016). Acute salt exposure of the freshwater Characiformes: Pacu (Piaractus mesopotamicus, Holmberg 1887), Tambaqui (Colossoma macropomum, Cuvier 1818), and their hybrid "Tambacu". Aquaculture, 465, 352-358.

Tamkeen, N., Rangoonwala, S., \& Rana, A. (2016). Temperature tolerance and hypoxia tolerance within and among the species of ribbon fish. International Journal of Scientific Research, 5(8), 145-148.

Tietze, S.M. (2016). Effects of salinity and pH change on the physiology of an estuarine fish species,
Fundulus heteroclitus heteroclitus. (2016). Electronic Theses \& Dissertations. Georgia Southern University, $43 \mathrm{pp}$.

Webb, A.C. (2008). Risk assessment model development for establishment success and impact of nonnative freshwater fishes in the wet tropics bioregion, northern queensland, australia. Report 08/23. Australian Centre for Tropical Freshwater Research, James Cook University, Townsville.

Wilkie, M.P., Simmons, H.E., \& Wood, C.M. (1996). Physiological adaptations of rainbow trout to chronically elevated water $\mathrm{pH}$ (pH 9.5). Journal of Experimental Zoology, 274, 1-14.

Wilson, J.M., Iwata, K., Iwama, G.K., \& Randall, D.J. (1998). Inhibition of ammonia excretion and production in rainbow trout during severe alkaline exposure. Comparative Biochemistry and Physiology, 121, 99-109.

Yurisman. (2009). The influence of injection ovaprim by different dosage to ovulation and hatching of tambakan (Helostoma temminckii C.V). Berkala Perikanan Terubuk, 37(1), 68-85. 